US Army Corps

of Engineers ${ }_{\circledast}$

Engineer Research and

Development Center

Water Operations Technical Support (WOTS) Program

Evaluation of Water

Quality/Environmental Management

Surveys on USACE Managed Reservoirs and Waterways

Victor F. Medina, Afrachanna D. Butler, Erich B. Emery,

and Gerard A. "Tony" Clyde

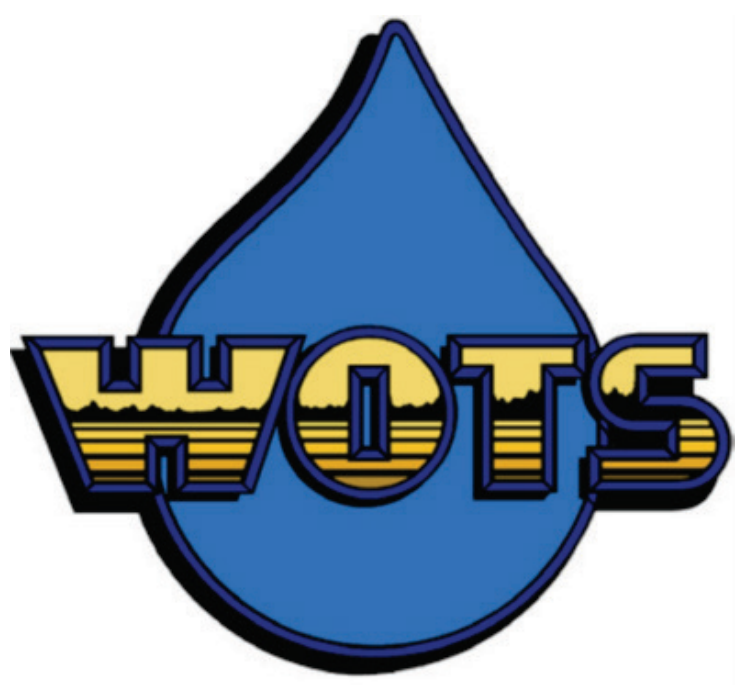


The U.S. Army Engineer Research and Development Center (ERDC) solves the nation's toughest engineering and environmental challenges. ERDC develops innovative solutions in civil and military engineering, geospatial sciences, water resources, and environmental sciences for the Army, the Department of Defense, civilian agencies, and our nation's public good. Find out more at www.erdc.usace.army.mil.

To search for other technical reports published by ERDC, visit the ERDC online library at http://acwc.sdp.sirsi.net/client/default. 


\title{
Evaluation of Water Quality/Environmental Management Surveys on USACE Managed Reservoirs and Waterways
}

\author{
Victor F. Medina and Afrachanna D. Butler \\ Environmental Laboratory \\ U.S. Army Engineer Research and Development Center \\ 3909 Halls Ferry Road \\ Vicksburg, MS 39180-6199 \\ Erich B. Emery \\ U.S. Army Corps of Engineers \\ Great Lakes and Ohio River Division \\ 550 Main Street, Room 10-032 \\ Cincinnati, $\mathrm{OH}$ 45202-3222 \\ Gerald A. "Tony” Clyde Jr. \\ U.S. Army Corps of Engineers \\ Tulsa District \\ 1645 South 101st East Ave \\ Tulsa, OK 74128-4609
}

Final Report

Approved for public release; distribution unlimited.

Prepared for Headquarters, U.S. Army Corps of Engineers

Washington, DC 20314-1000

Under Program Number TA2017-003 


\section{Abstract}

This technical report (TR) details the results of a water quality/environmental management (WQ/EM) survey that was provided to U.S. Army Corps of Engineers (USACE) districts and divisions. The WQ/EM survey found that flood risk management was the most important congressionally authorized purpose, and was the highest funded activity. These results were followed by water quality, navigation, and recreation for importance. Agricultural impacts (i.e., nutrients, erosion, and pesticides) were the most critical upstream factors affecting WQ/EM. Critical reservoir factors were fisheries and algal blooms. In most cases, the results showed that there were very broad sets of WQ/EM purposes, factors, and issues. Limited resources in terms of funds and personnel will have to be applied to maximize positive benefits.

DISCLAIMER: The contents of this report are not to be used for advertising, publication, or promotional purposes. Citation of trade names does not constitute an official endorsement or approval of the use of such commercial products. All product names and trademarks cited are the property of their respective owners. The findings of this report are not to be construed as an official Department of the Army position unless so designated by other authorized documents. 


\section{Contents}

Abstract
Figures and Tables.

1.8 Water quality data collection and reporting ........................................................ 8

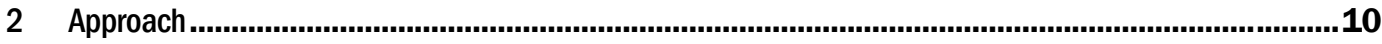

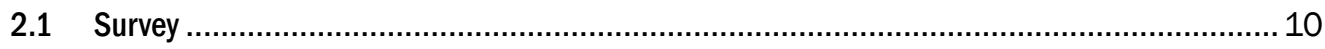

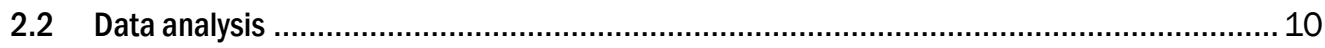

3 Results .......................................................................................................................................12

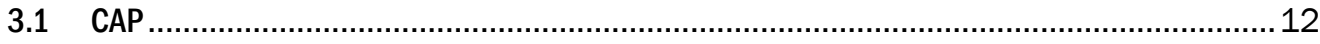

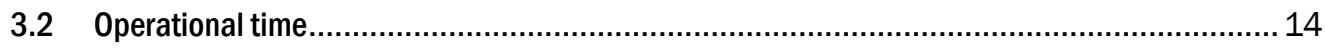

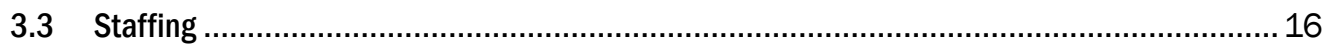

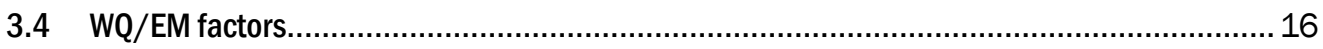

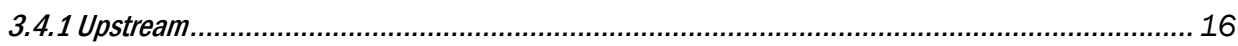

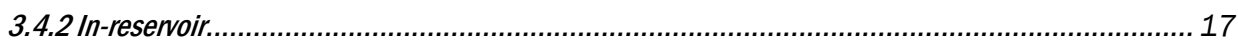

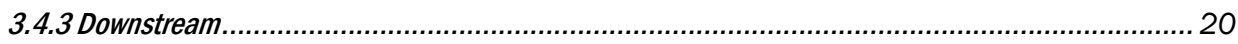

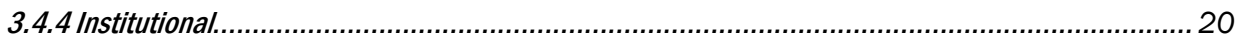

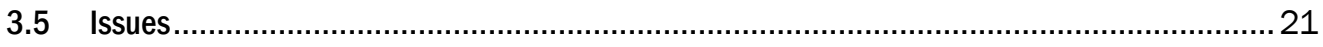

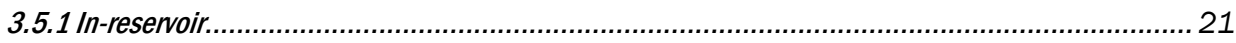

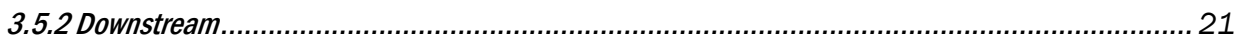

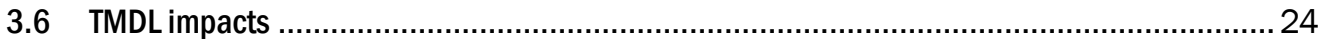




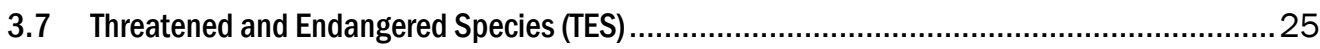

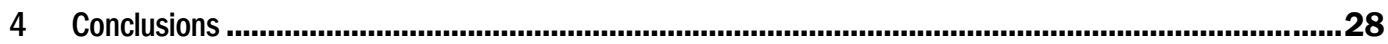

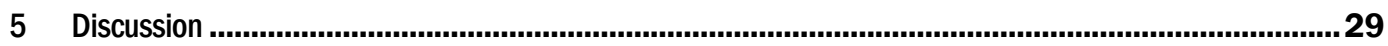

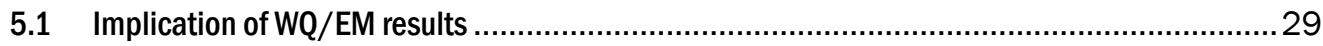

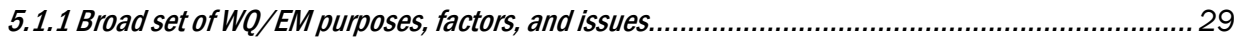

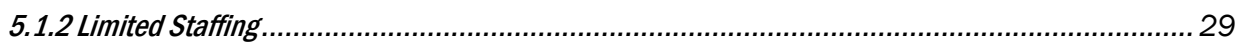

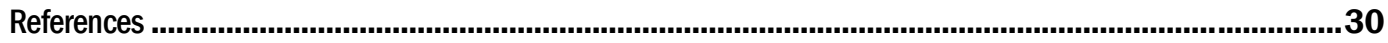

Report Documentation Page 


\section{Figures and Tables}

\section{Figures}

Figure 1. 2009 Assessment of factors effecting changes to reservoir operations (adapted from USACE-IWR 2016b).

Figure 2. Summary of CAPs for survey data from six USACE divisions....................................................... 13

Figure 3. Operational time devoted to each CAP annually (see acronym/abbreviation list). .............................. 15

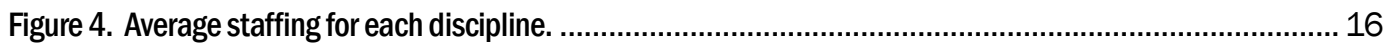

Figure 5. Upstream factors affecting WQ/EM for reporting districts in six USACE divisions. ..............................18

Figure 6. In-reservoir factors affecting WQ/EM for reporting districts in six USACE divisions. .............................. 19

Figure 7. Downstream factors affecting WQ/EM for reporting districts in six USACE divisions............................20

Figure 8. Institutional factors affecting WQ/EM for reporting districts in six USACE divisions. ........................... 21

Figure 9. Top 20 In-Reservoir WQ/EM issues. .................................................................................. 22

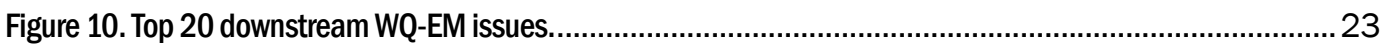

Figure 11. Number of TES Influences as reported by the districts responding to the WQ/EM survey. ...................26

\section{Tables}

Table 1. Participating USACE divisions and districts.

Table 2. Number of Mississippi River crests in the past ten years that rank among the top ten highest historically measured for three locations (Frankel 2018). ................................................ 5

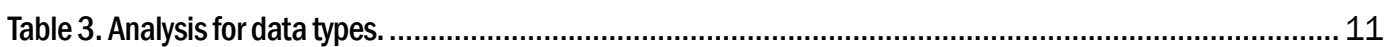

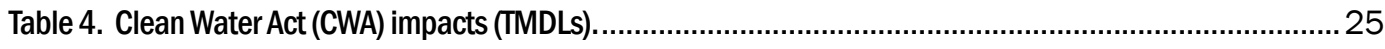

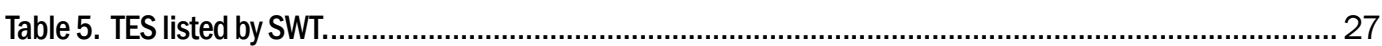




\section{Preface}

This work was conducted by the Environmental Engineering Branch (EPE) at the U.S. Army Engineer Research and Development Center (ERDC), Environmental Laboratory (EL), Vicksburg, MS. The project was funded by the Water Operations Technical Support (WOTS) program, TA2017oo3, managed by Dr. Pat Deliman.

At the time of publication of this report, Dr. W. Andy Martin was Chief of the Environmental Engineering Branch (CEERD-EPE); Mr. Jared Johnson was Chief of the Environmental Processes and Engineering Division (CEERD-EP); Dr. Pat Deliman was the WOTS Technical Director. Dr. Jack E. Davis was the Deputy Director, and Dr. Ilker R. Adiguzel was the Director of EL.

COL Ivan P. Beckman was Commander of ERDC, and Dr. David W. Pittman was the Director. 


\section{Acronyms and Abbreviations}

$\begin{array}{ll}\text { APCRP } & \text { Aquatic Plant Control Research Program } \\ \text { CAP } & \text { Congressionally Authorized Purpose(s) } \\ \text { CWA } & \text { Clean Water Act } \\ \text { DO } & \text { Dissolved Oxygen } \\ \text { DoD } & \text { Department of Defense } \\ \text { DOTS } & \text { Dredging Operations Technical Support } \\ \text { EAL } & \text { Environmentally Acceptable Lubricant(s) } \\ \text { EL } & \text { Environmental Laboratory } \\ \text { EM } & \text { Environmental Management } \\ \text { EPE } & \text { Environmental Engineering Branch } \\ \text { EP } & \text { Environmental Processes and Engineering Division } \\ \text { ERDC } & \text { Engineer Research and Development Center } \\ \text { ft } & \text { foot } \\ \text { FTE } & \text { Full Time Equivalent(s) } \\ \text { HAB(s) } & \text { Harmful Algal and Cyanobacterial Bloom(s) } \\ \text { IWR } & \text { Institute for Water Resources } \\ \text { LRB } & \text { Buffalo District } \\ \text { LRD } & \text { Great Lakes and Ohio River Division } \\ \text { LRE } & \text { Detroit District } \\ \text { LRH } & \text { Huntington District } \\ \text { LRL } & \text { Louisville District } \\ \text { LRN } & \text { Nashville District } \\ \text { LRP } & \text { Pittsburg District } \\ \text { M\&I } & \text { Municipal and Industrial } \\ \text { MVD } & \text { Mississippi Valley Division } \\ \text { MVK } & \text { Vicksburg District } \\ \text { MVM } & \text { Memphis District } \\ \text { MVN } & \text { New Orleans District } \\ & \end{array}$




\begin{tabular}{ll} 
MVP & St. Paul District \\
MVS & St. Louis District \\
MVR & Rock Island District \\
N/A & Not Applicable \\
NAB & Baltimore District \\
NAD & North Atlantic Division \\
NAE & New England District \\
NAO & Norfolk District \\
NAP & Philadelphia District \\
NAVSYS & Navigation Systems \\
NPA & National Portfolio Assessment \\
NPDES & National Pollution Discharge Elimination System \\
NWD & Northwestern Division \\
NWK & Kansas City District \\
NWO & Omaha District \\
NWP & Portland District \\
NWS & Seattle District \\
NWW & Walla Walla District \\
O\&M & Operations and Maintenance \\
SAC & Charleston District \\
SAD & South Atlantic Division \\
SAJ & Jacksonville District \\
SAM & Mobile District \\
SAS & Savannah District \\
SAW & Wilmington District \\
SPD & South Pacific Division \\
SWD & Southwestern Division \\
SWG & Galveston District \\
SWL & Little Rock District \\
\hline
\end{tabular}




$\begin{array}{ll}\text { SWT } & \text { Tulsa District } \\ \text { TES } & \text { Threatened and Endangered Species } \\ \text { TMDL } & \text { Total Maximum Daily Loads } \\ \text { TR } & \text { Technical Report } \\ \text { U.S. } & \text { United States } \\ \text { USACE } & \text { United States Army Corps of Engineers } \\ \text { WOTS } & \text { Water Operations Technical Support program } \\ \text { WQ } & \text { Water Quality }\end{array}$




\section{Introduction}

\subsection{Background}

The U.S. Army Corps of Engineers (USACE) manages and operates a wide range of waterways throughout the United States (U.S.), including 402 dams and reservoirs, 12,000 miles of inland and intracoastal waterway navigable channels that include 192 commercial locks and dams, and is responsible for ports and waterways in 41 states (USACE-IWR 2010). The primary purpose of USACE dams is to promote navigation on inland rivers and control flooding. However, the dams also have many secondary purposes, including electrical power generation, reservoirs, recreation and water quality (USACE-IWR 2016b). Water managers must balance a wide array of concerns. Among those are issues associated with water quality (WQ) and environmental management (EM). A detailed survey (described in section 2) was submitted to USACE districts to assess WQ/EM issues in USACE managed waterways.

\subsection{Survey}

The goals behind the survey are outlined in a cover letter sent to the USACE districts (Webb and Hillyer 2008), which states:

"The purpose of this study is to develop a portfolio of Corps multipurpose projects that can be used as a screening tool to identify the best candidates for opportunities for operational changes and/or reallocation opportunities to insure existing Corps reservoirs contribute to enhance economic and ecosystem values as water demands evolve and better understanding of global warming issues are evaluated."

\subsection{Objective}

The objective of this technical report (TR) is to summarize results of surveys on WQ/EM conducted by the USACE Committee on Water Quality. The goal of the survey was to refine and prioritize challenges and needs in WQ/EM. In doing so, the report meets the objectives of the Institute of Water Resources' (IWR) National Portfolio Assessment (NPA), which identified the need for such a survey (USACE-IWR 2016a). 


\subsection{Scope}

The scope of the project spanned most of the USACE districts. Six of the seven USACE divisions and 23 out of 35 USACE districts responded to the survey (Table 1). Two districts determined that the survey was not applicable to them. Ten districts did not respond at all, either they did not have the resources, or they determined that the survey was not applicable to them.

Table 1. Participating USACE divisions and districts.

\begin{tabular}{|l|l|}
\hline Divisions & Districts \\
\hline \multirow{5}{*}{ LRD - Great Lakes and Ohio River } & LRE - Detroit \\
& LRP - Pittsburg \\
& LRH - Huntington \\
& LRL - Louisville \\
& LRN - Nashville \\
& LRB - Buffalo \\
\hline \multirow{5}{*}{ MVD - Mississippi Valley } & MVP - St. Paul \\
& MVR - Rock Island \\
& MVS - St. Louis \\
& MVK - Vicksburg \\
& MVM - Memphis \\
& MVN - New Orleans \\
\hline \multirow{5}{*}{ NAD - North Atlantic } & NAB - Baltimore \\
& NAO - Norfolk \\
& NAP - Philadelphia \\
& NAE - New England \\
\hline SAD - South Atlantic & NWS - Seattle \\
& NWP - Portland \\
& NWW - Walla Walla \\
& NWK - Kansas City \\
& NWO - Omaha \\
\hline SWD - Southwest & SWL - Little Rock \\
& SWT - Tulsa \\
& SWG - Galveston \\
\hline & SAJ - Jacksonville \\
& SAW - Wilmington \\
& SAC - Charleston \\
& SAS - Savannah \\
& SAM - Mobile \\
\hline & \\
\hline \multirow{5}{*}{ Northwest } &
\end{tabular}




\subsection{Congressionally Authorized Purpose (CAP)}

USACE reservoirs were constructed with a specific purpose or set of purposes. The Congressionally Authorized Purpose(s) (CAP) describe the specific purposes a reservoir is to serve as specified in laws that either (1) initiated construction of the project, (2) are specific to that project and were passed after construction, and (3) apply generally to all USACE reservoirs (e.g., the Endangered Species Act, which provides authority for operating projects to protect listed species) (USACE 2017).

As indicated in USACE (2017), common CAPs are

- Flood control.

- Navigation.

- Hydroelectric power generation.

- Irrigation.

- Water supply (municipal and industrial (M\&I)).

- Water quality.

- Fish and wildlife.

- Recreation.

- Sediment control.

Some water resource projects have a single purpose; however, most projects have multiple purposes. For example, Columbia River dams like John Day, the Dalles, and McNary are primarily navigation dams, but these also provide flood control, hydroelectric power, and recreation. In addition, their operation is affected by water supply, water quality, and fish and wildlife concerns. The Blue River, Cougar, and Hills Creek Dams in Oregon are, on the other hand, primarily flood control dams, although both Cougar and Hills Creek do have hydropower production as well (Medina et al. 2018A).

USACE-IWR (2016b) presented results of an analysis conducted in 2009 of the key factors that create changes in reservoir operation, these are summarized in Figure 1. Flood control is the most critical, affecting $41 \%$ of the changes. However, WQ-EM (referred to FW-WQ [fish, wildlife and water quality] in the report) was also an important factor, accounting for $14 \%$ of the changes, just behind water supply. Furthermore, the analysis showed that WQ-EM had grown from only about $1 \%$ in 1970 , and it was the factor that had the most growth. Therefore, WQ-EM has even become more important from 2009 to now (2019). 
Figure 1. 2009 Assessment of factors effecting changes to reservoir operations (adapted from USACE-IWR 2016b).

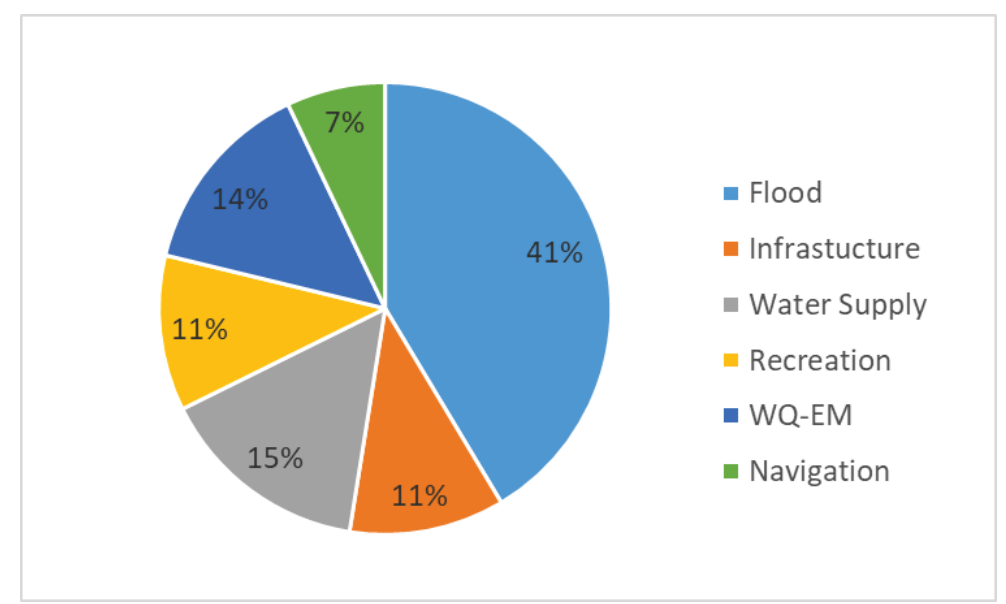

\subsection{Primary water project operation purposes}

USACE (2017) discusses several key purposes for USACE water project operations, these are discussed the subsequent sections.

\subsubsection{Flood risk management}

Dams and reservoirs provide excellent capabilities to minimize flood risks. Reservoirs can contain large flows of water that may otherwise flood a watershed, then release the accumulated water in moderate quantities over time. However, very large flood events could actually overwhelm the storage capacity of a reservoir. In that case, the system must be managed to protect the reservoir so it does not breach and create a catastrophic release of its stored water. USACE-IWR (2016a) indicated that $41 \%$ of operating changes at USACE projects can be attributed to flood risk management activities, and that this was the most common reason for operational change. Frankel (2018) reports that the Mississippi River has, within the last seven years, been subject increasingly frequent and severe flood events, including 100-, 200-, and 500-year floods (Table 2). Frankel (2018) also discusses the complexity of managing the flow of the Mississippi River to manage flood risk while addressing desires of local communities and states to increase levy size and accept less water releases. USACE (2017) discusses flood risk management approaches in detail (http://www.publications.usace.army.mil/Portals/76/Publications/EngineerManuals/EM_1110-23600.pdf). 
Table 2. Number of Mississippi River crests in the past ten years that rank among the top ten highest historically measured for three locations (Frankel 2018).

\begin{tabular}{|l|c|}
\hline Location & Number of top ten flood events within the last ten years \\
\hline Brainerd, MN & 5 \\
\hline Hannibal, MO & 4 \\
\hline Natchez, MS & 3 \\
\hline
\end{tabular}

\subsubsection{Navigation}

Navigation is the original civilian mission of the USACE. Dams and lock structures allow shipping to adjust to elevation changes in rivers. Reservoirs slow water, making navigation easier. Pools can allow shipping to access portions of rivers that were previously too shallow. USACE (2017) discusses navigation in detail (http://www.publications.usace.army.mil/Portals/76/Publications/EngineerManuals/EM_1110-23600.pdf).

Lock and dam structures allow shipping to navigate through elevation changes in rivers. For example, there are 29 lock and dam structures on the Mississippi river that allow shipping to navigate through a $420 \mathrm{ft}$ elevation change along the 670 mile river (Frankel 2018). Barge traffic is estimated to move 300 million tons of goods annually within the Mississippi River system (Frankel 2018).

Navigation may require activities that affect WQ-EM. Dredging may be periodically required to keep channels deep enough for shipping, this can result in sediment suspension and contaminant release. Concrete mats are commonly placed to protect channels from erosion, which can affect sediment/water column interactions (Frankel 2018). Lubricants have also become an area of concern and the USACE has been studying the implementation of environmentally acceptable lubricants (EAL) (Medina 2015; Paulus et al. 2018; Medina et al. 2018C).

\subsubsection{Hydropower}

USACE dams were constructed for primary purposes other than hydropower. However, many projects include hydropower and the USACE actually manages the highest electrical production than any other U.S. organization (Medina et al. 2018C). Hydropower is typically operated at a relatively smooth level, with allied fossil fuel, nuclear, or renewable power 
available to account for periods of high energy needs. Therefore, water discharges for hydropower are generally constant, with gradual changes of flow. Hydropower turbines can limit the ability of a dam to release water, as most turbines have limitations on the water flow that can be passed through them. Therefore, dams with high flood control missions may have limited or no hydropower capabilities. Fish passage has long been a critical issue for large issues for dams with hydropower capability. In addition, implementation of EALs is becoming more common, and the latest USACE policy now specifies that EALs should be used when possible (Stockton 2019).

\subsubsection{Water supply}

Water releases may be governed by the need to provide water supply downstream of the dam. Communities, industries, or irrigation systems require water, and reservoir releases are often necessary to provide this supply. This was actually identified as the second most common reason for operational change (15\%) by the USACE-IWR (2016a).

\subsubsection{Recreation}

Recreation has become an extremely important issue for USACE dams. This includes swimming, boating, water skiing, and other water contact activities. Fishing is a popular activity, so protecting fish populations is critically important. Hunting, birdwatching, and wildlife appreciation requires that water projects provide habitat where wildlife can thrive. Also, many recreational visitors are interested in seeing beautiful vistas and want reservoirs and lakes to be visually appealing. Downstream releases may govern river fishing, white water rafting and canoeing, and other recreational activities.

\subsubsection{Environmental}

Water releases are often performed for environmental purposes. According to USACE-IWR (2016a), environmental purposes is among the top three reasons for operating change (14\%). Water releases can be used to address downstream issues including temperature (usually related to fish habitat), and allow sufficient flow for fish migration. In reservoir issues can also addressed, water releases can allow for mixing to address temperature, dissolved oxygen (DO), and algal issues. USACE-IWR (2016a) provides examples of studies that show even relative minor 
adjustments to operational water releases can improve environmental quality.

\subsubsection{Other}

Other important activities include

- Management of sedimentation in-reservoir.

- Downstream erosion.

- Impact on climate change.

\subsection{Water quality parameters of interest for water operations projects}

USACE (2018) indicates that USACE civil projects must comply with federal regulations, including the Federal Water Pollution Control Act of 1946 and the Clean Water Act (CWA) of 1977, and the Water Quality Act of 1987. No degradation of water quality is allowed without substantial proof that such an impact will not affect the integrity of the stream.

\subsubsection{Nutrients}

Nutrients (mostly nitrogen and phosphorus) are a key issue in WQ/EM primarily because they promote eutrophication, which is an overstimulation of the production of organic material (primarily as algae and cyanobacteria) in the water body. Phosphorus is generally considered the most critical because a small change in phosphorus can have a great effect on biological growth. Eutrophication can have several negative consequences including the following:

- Discoloration of the water.

- Formation of taste and odor compounds that can compromise the water as a drinking water source.

- Oxygen depletion, particularly at depth in a stratified water body.

- Formation of anoxic gases, like hydrogen sulfide and ammonia, which are foul smelling and can have negative health impacts at higher concentrations.

- Release of metals contained in sediments due to acidic forming reactions from the transformation of anoxic gases.

- Change of habitat that generally does not favor fish most prized for commercial production or recreational fishing. 
- Formation of cyanobacterial/algal blooms, which can negatively impact human health, pets, and livestock.

Medina et al. (2018B) provides a detailed discussion of nutrients (particularly phosphorus) and methods to address them.

\subsubsection{Algal issues}

Algal issues (those involving excessive algae and cyanobacterial growth) is closely linked to nutrients (see section 1.8.1). Many of the negative issues associated with eutrophication are the result of algal growth. Excessive algal growth of any kind is undesirable. Of particular concern are blooms involving species that release toxins, which are referred to harmful algal blooms (HABs).

An allied survey was conducted focusing on HABs indicating that 13 of the 14 districts surveyed had $\mathrm{HAB}$ events ranging from 0.5 (on average) to more than 14 events per year ${ }^{1}$. Cyanobacteria were by far the most prevalent cause of a HAB event, however, dinoflagellates and Prymnesiophyta were also reported.

Herman et al. (2017) presents an overview of useful approaches for addressing HABs in USACE reservoirs, these efforts range from water control management methods, in situ treatment, and nutrient control. Several examples of reservoirs addressing HAB problems are also provided.

\subsubsection{Thermal}

Reservoirs slow and pool water, allowing it to be heated over time and increase in temperature. This increased temperature can affect fish populations within the reservoir and downstream. Therefore, water releases may, at times, be governed by the need to manage water temperatures.

\subsection{Water quality data collection and reporting}

USACE (2018) specifies conditions in which water quality data must be collected. This includes the need to establish baseline conditions and identify trends for potential impacts. Collection is also required to

1 allied survey 
determine compliance with federal, state, and local water quality standards. Additional sampling may be required to investigate special problems and impacts of design modifications. Data collection may be needed to monitor engineer aquatic environments or ecosystems or to monitor swimming beaches and recreational areas.

Water quality results are reported in published reports. These include project specific reports, needs assessment reports, special situation or studies, and annual water quality reports (USACE 2018). 


\section{Approach}

\subsection{Survey}

The extensive survey could be divided into various parts, each focused on assessing specific aspects of WQ/EM. These include the following:

- CAPs.

- Staffing - an assessment of professionals focused on WQ/EM.

- Upstream, in-reservoir, and downstream factors that drive WQ/EM operations.

- Institutional factors that drive WQ/EM.

- WQ/EM issues both in-reservoir and downstream.

- Operational time devoted to WQ/EM activities.

Funding was an important portion of the survey, but unfortunately, it was found that the different districts reported their funding in different ways and using different units. These differences were not completely resolved and it was decided to remove this analysis.

\subsection{Data analysis}

For the purpose of this presentation, data from the various divisions was summarized to a single number, then this was totaled to a single number for all USACE. Table 3 summarizes how data was analyzed. 
Table 3. Analysis for data types.

\begin{tabular}{|c|c|c|}
\hline Type of Data & Data Units & Analysis Approach \\
\hline $\begin{array}{l}\text { Congressionally Authorized } \\
\text { Purpose (CAP) } \\
\text { Operational time } \\
\text { Time for water management }\end{array}$ & Percentage & $\begin{array}{l}\text { Each data type was summarized, and divided } \\
\text { by number of data points, to normalize at } \\
100 \% \text {. }\end{array}$ \\
\hline $\begin{array}{l}\text { Staffing } \\
\text { WQ/EM funding }\end{array}$ & Number & $\begin{array}{l}\text { All numbers totalized for each category and } \\
\text { divided by the number of responding districts. }\end{array}$ \\
\hline $\begin{array}{l}\text { WQ/EM upstream factors } \\
\text { In-reservoir factors } \\
\text { Downstream factors } \\
\text { Institutional factors }\end{array}$ & N/A, Low, Medium, High & $\begin{array}{l}\text { Responses scored: } \\
\mathrm{N} / \mathrm{A}=0 \\
\text { Low }=1 \\
\text { Medium }=2 \\
\text { High }=3\end{array}$ \\
\hline $\begin{array}{l}\text { Issues in-reservoir } \\
\text { Issues downstream }\end{array}$ & $\begin{array}{l}\text { N/A, Emerging, Existing, } \\
\text { Low, Medium, High }\end{array}$ & $\begin{array}{l}\mathrm{N} / \mathrm{A}=0 \\
\text { Emerging = } 1 \\
\text { Existing = } 2 \\
\text { Low }=3 \\
\text { Medium = } 4 \\
\text { High }=5\end{array}$ \\
\hline $\begin{array}{l}\text { Total Maximum Daily Loads } \\
\text { (TMDL)/Clean Water Act }\end{array}$ & Yes and No & $\begin{array}{l}\text { Yes and no responses were totaled to give a } \\
\text { total number of projects. Then, the yes } \\
\text { responses were divided by the total responses } \\
\text { to give a percentage of projects effected by } \\
\text { TMDL/CWA per category. }\end{array}$ \\
\hline
\end{tabular}




\section{Results}

\subsection{CAP}

Figure 2 shows the results of the survey question seeking to characterize the average time spent in support of congressionally authorized reservoir purposes. Percentages reflect a current and typical workload for the entire responding office, and for its whole portfolio of survey reservoirs. The survey revealed that staff spent the most time, over $30 \%$, operating projects to meet flood risk management goals. Water quality was second at $12 \%$. The traditional role of the USACE, to provide navigation, was $6 \%$. However, it is interesting that this was only third in importance in the surveys. Several other CAPs have similar responses to navigation (4-6\%) including fish and wildlife, other, municipal/industrial water supply, recreation, and hydroelectric power. This indicates that there are a broad set of competing purposes that must be considered when operating multipurpose projects. 
Figure 2. Summary of CAPs for survey data from six USACE divisions.

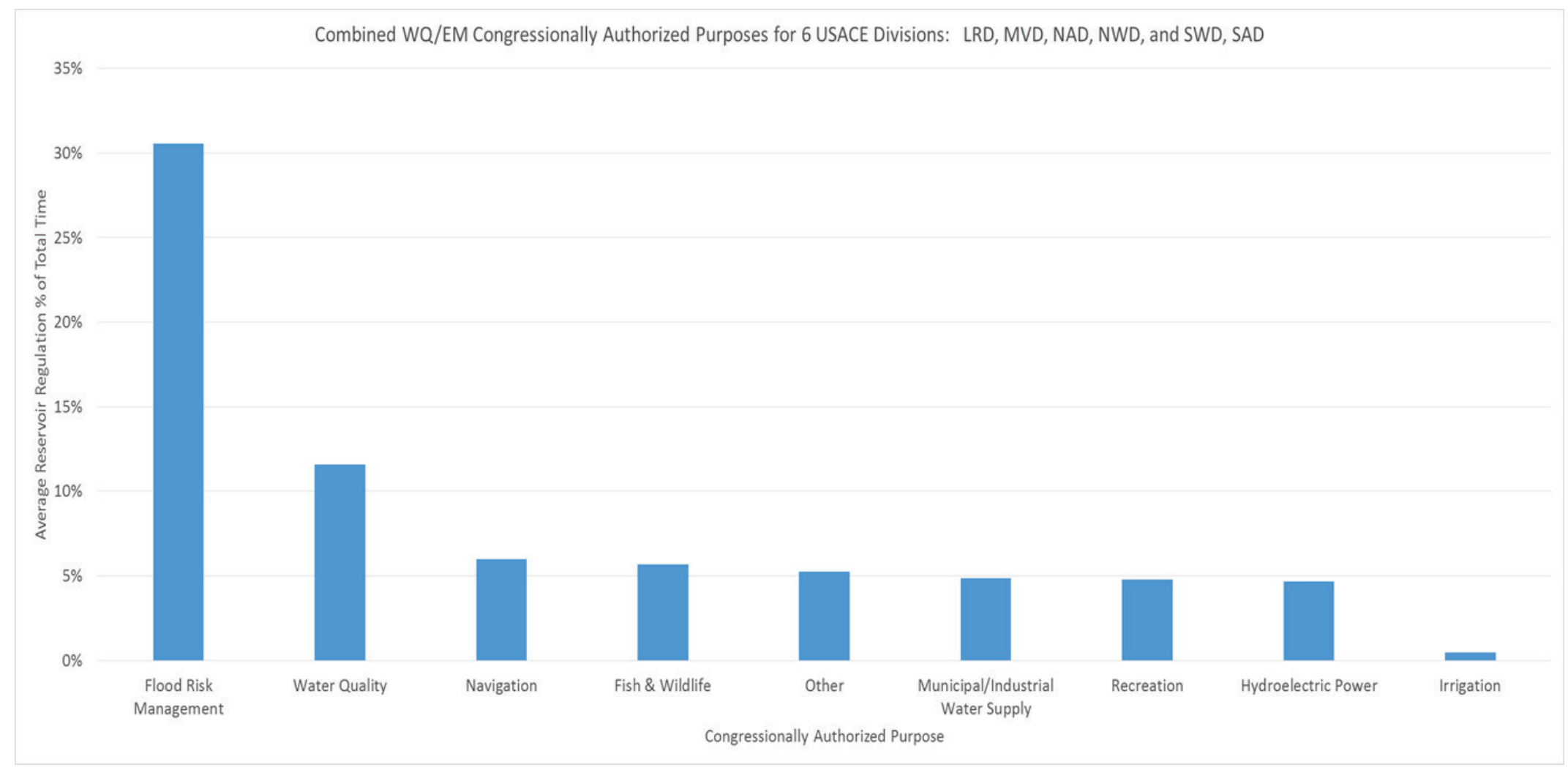




\subsection{Operational time}

Figure 3 shows different operational time commitments broken out by district. The most compelling feature of this graph is the wide range of priorities as shown in operational time from district to district. Even districts within the same division had tremendous variation. For example, LRE reported $100 \%$ operational time for navigation, while LRH, also a part of LRD, had no time reported for navigation.

In reviewing this data, it is important to be aware that the portfolio of projects operated by each of these districts is very different. For example, LRE has one project and LRH has thirty-five projects. The LRE project is a natural lake with a control structure on a natural waterway connecting this lake to another lake. The control structure is primarily used to augment flow for navigation. The district does not operate this project for other purposes. LRH has a large portfolio of multi-purpose projects operating primarily for flood control. So, the differences between the project portfolios is a major reason for the variety of operational time differences. 
Figure 3. Operational time devoted to each CAP annually (see acronym/abbreviation list).

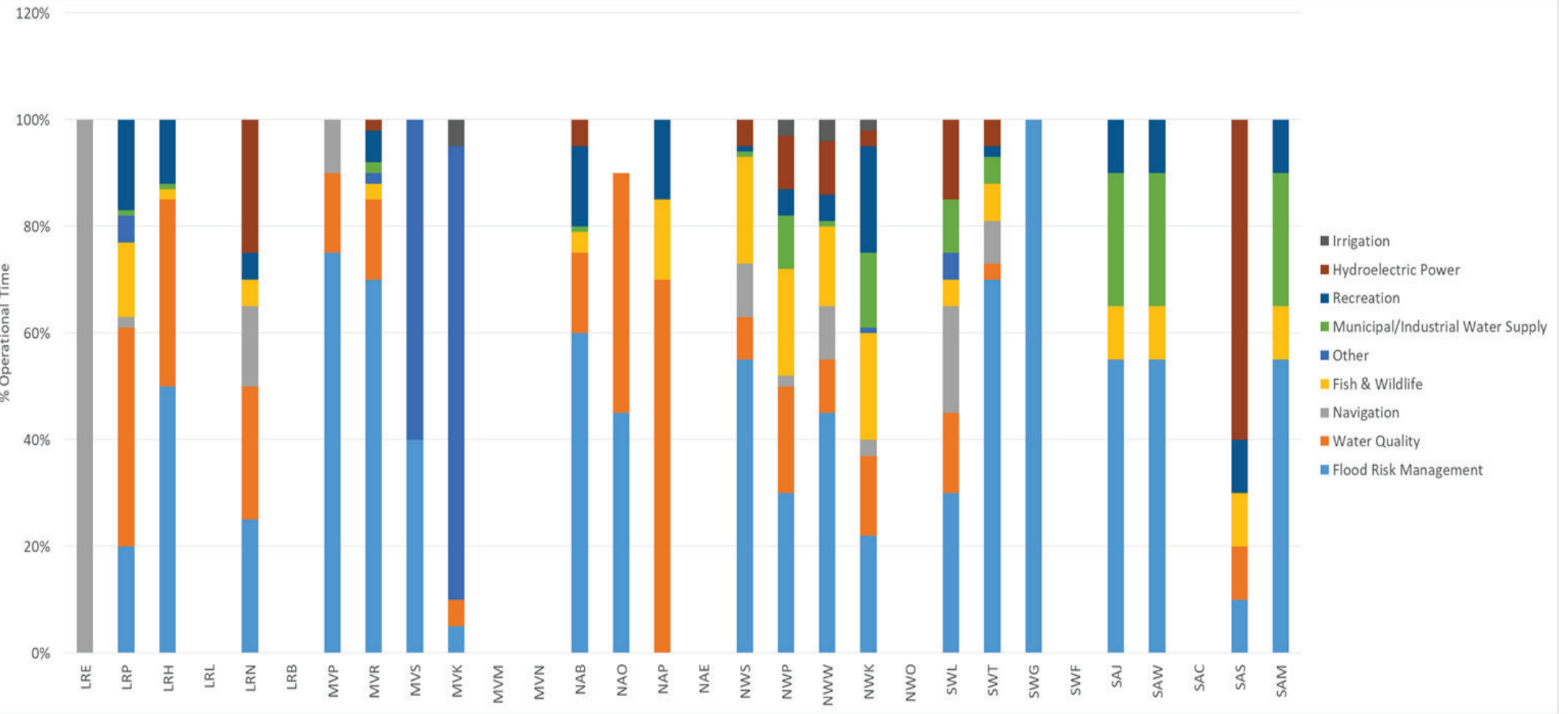




\subsection{Staffing}

Figure 4 summarizes staffing based on full time equivalent (FTE) per responding district. Adding these positions together gives an average of 1.86 FTE per district. The most common position is biologist, at $0.58 \mathrm{FTE}$ average. The second and third most common positions are hydrologist and hydraulic engineer, respectively. These are positions with similar skill sets and capabilities, and both are key positions for flood management, which was identified as the highest CAP (Figure 1). If these two positions are combined, they add up to $0.60 \mathrm{FTE}$, or slightly more than biologist. Limnologist and environmental engineers are the next two common positions. Comments indicated that water quality specialists were frequently located in planning branches, and not in the water management branches.

Figure 4. Average staffing for each discipline.

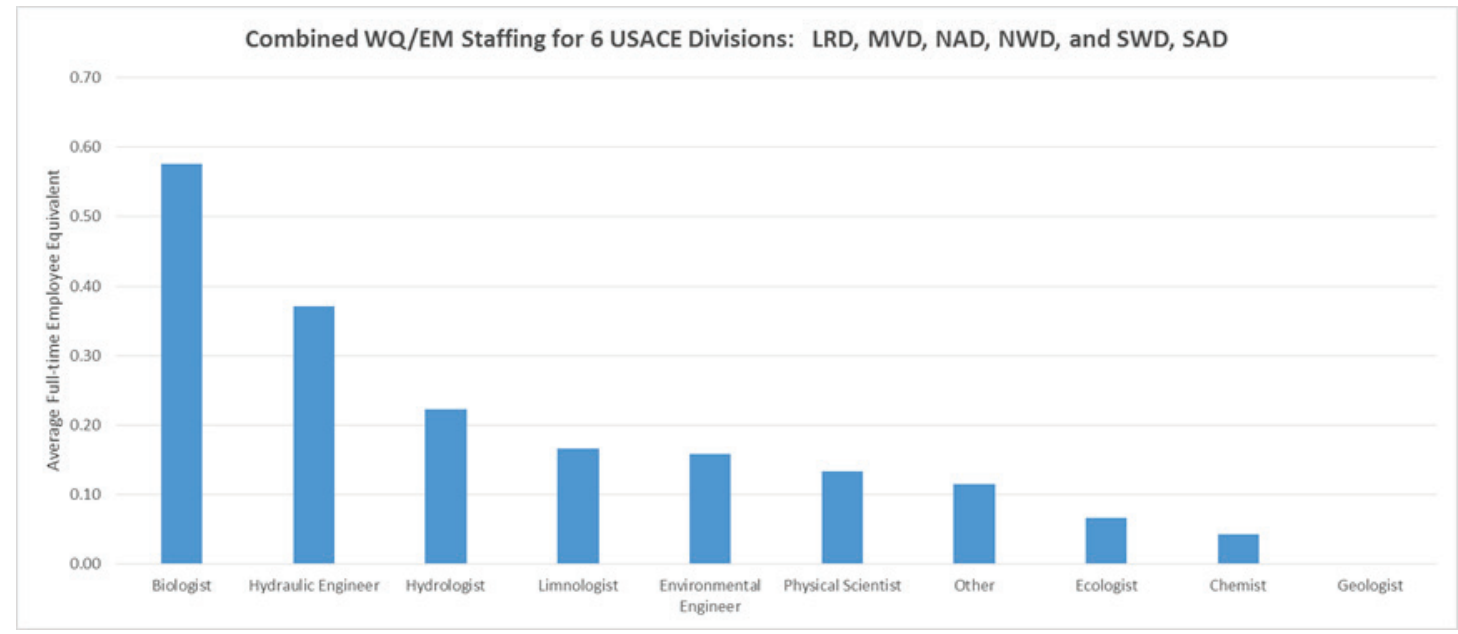

\subsection{WQ/EM factors}

WQ/EM factors are conditions that affect WQ/EM management. These may occur upstream in the watershed, within the reservoir, or downstream. The impact of a list of key factors (e.g., agricultural, urban, and industrial) was assessed by the survey.

\subsubsection{Upstream}

Figure 5 summarizes the survey results for most critical upstream issues. These are dominated by agricultural impacts, led by nutrients, erosion (upland and channel), and pesticides. Urban issues follow (runoff from 
impervious surfaces and nutrients). However, there was a long tail of additional issues with lesser, but still significant, scores.

\subsubsection{In-reservoir}

Figure 6 summarizes in-reservoir factors affecting WQ/EM according the survey results. Recreational use and in-lake fisheries were the highest factors rated followed by algal blooms. Two WQ issues followed, DO and thermal conditions. There were many other issues that received significant scores. 


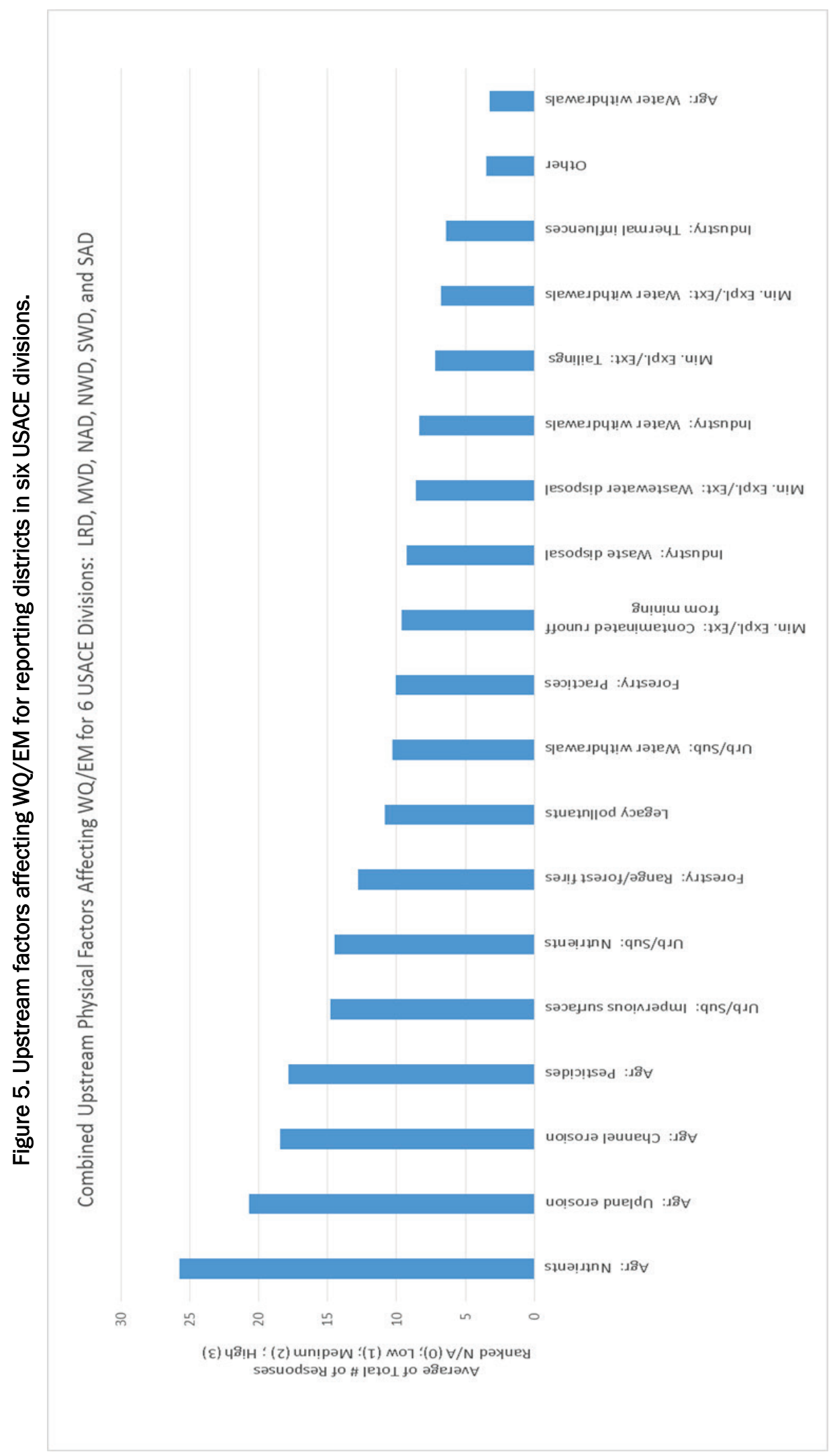




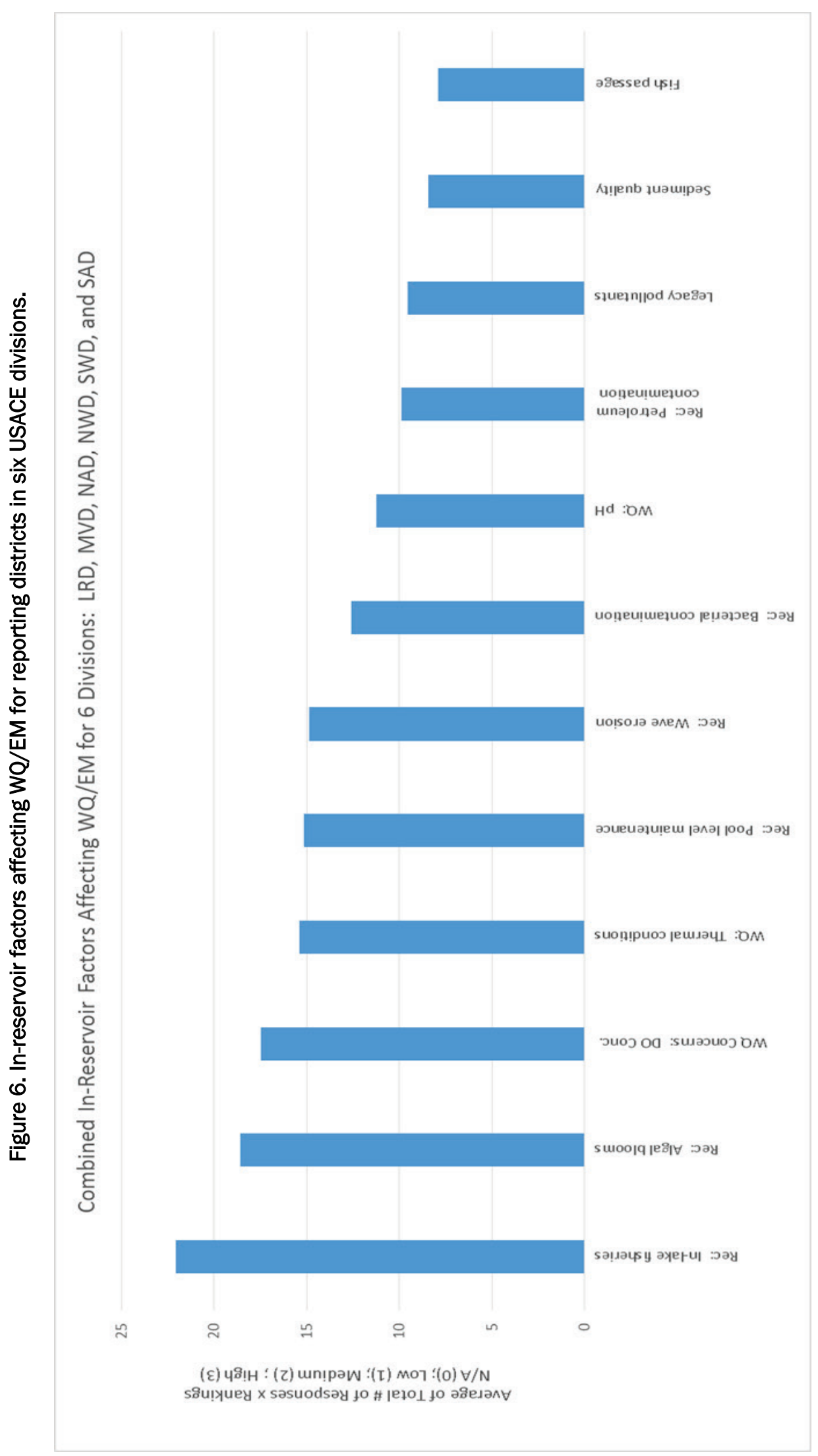




\subsubsection{Downstream}

Figure 7 summarizes downstream factors affecting WQ/EM as reported by the survey. These results indicate that several factors are important. Fisheries was the most important factor with a score of nearly 20. Ecological flow releases, temperature management, dilution, and recreation followed with scores of 13-15. Rafting was the lowest scored downstream activity with a 6 .

Figure 7. Downstream factors affecting WQ/EM for reporting districts in six USACE divisions.

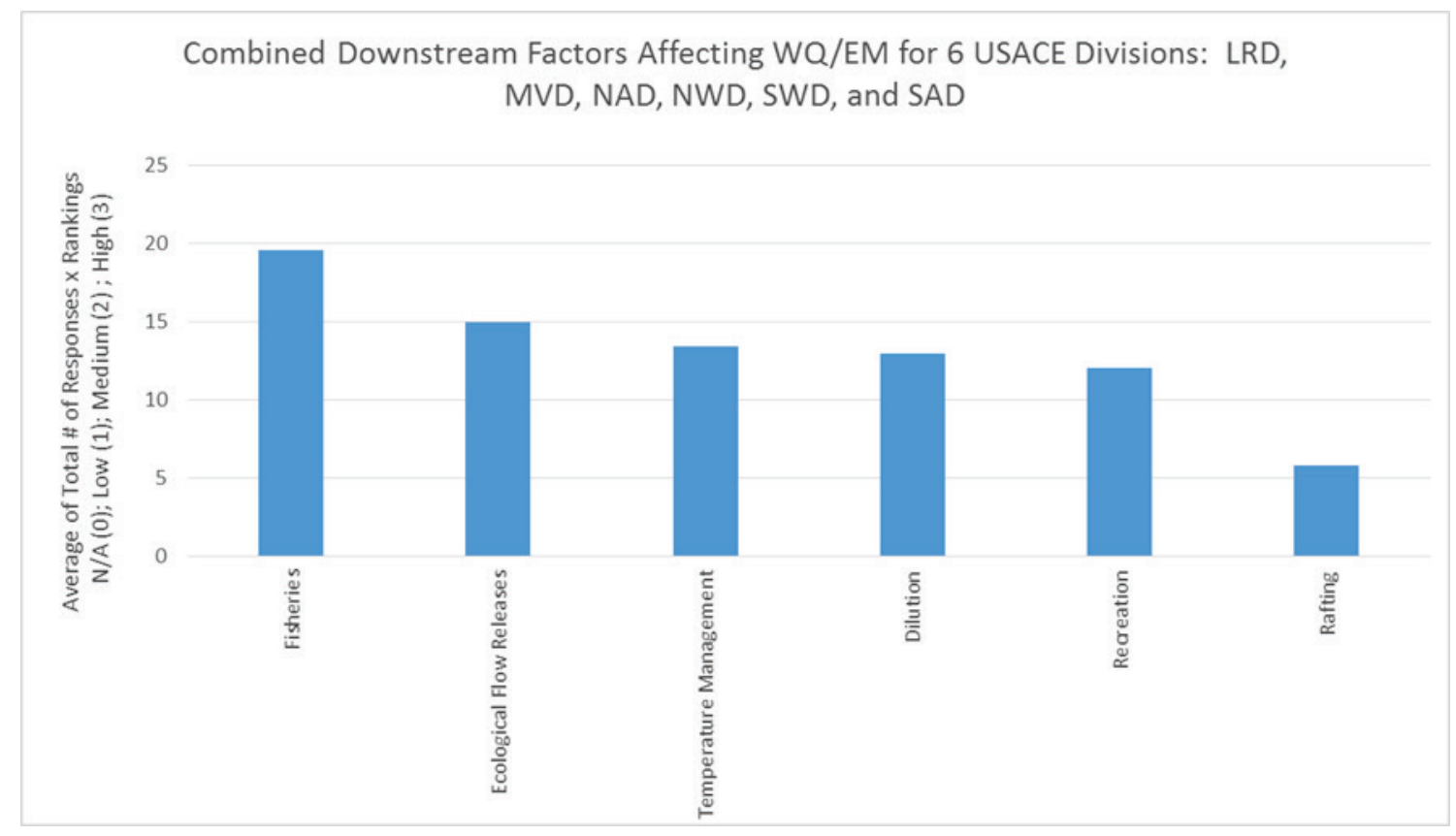

\subsubsection{Institutional}

Figure 8 lists institutional factors affecting WQ/EM. The top four were flood risk management, fish and wildlife, water quality, and recreation. However, there is a broad tail of other factors that received significant scores. 
Figure 8. Institutional factors affecting WQ/EM for reporting districts in six USACE divisions.

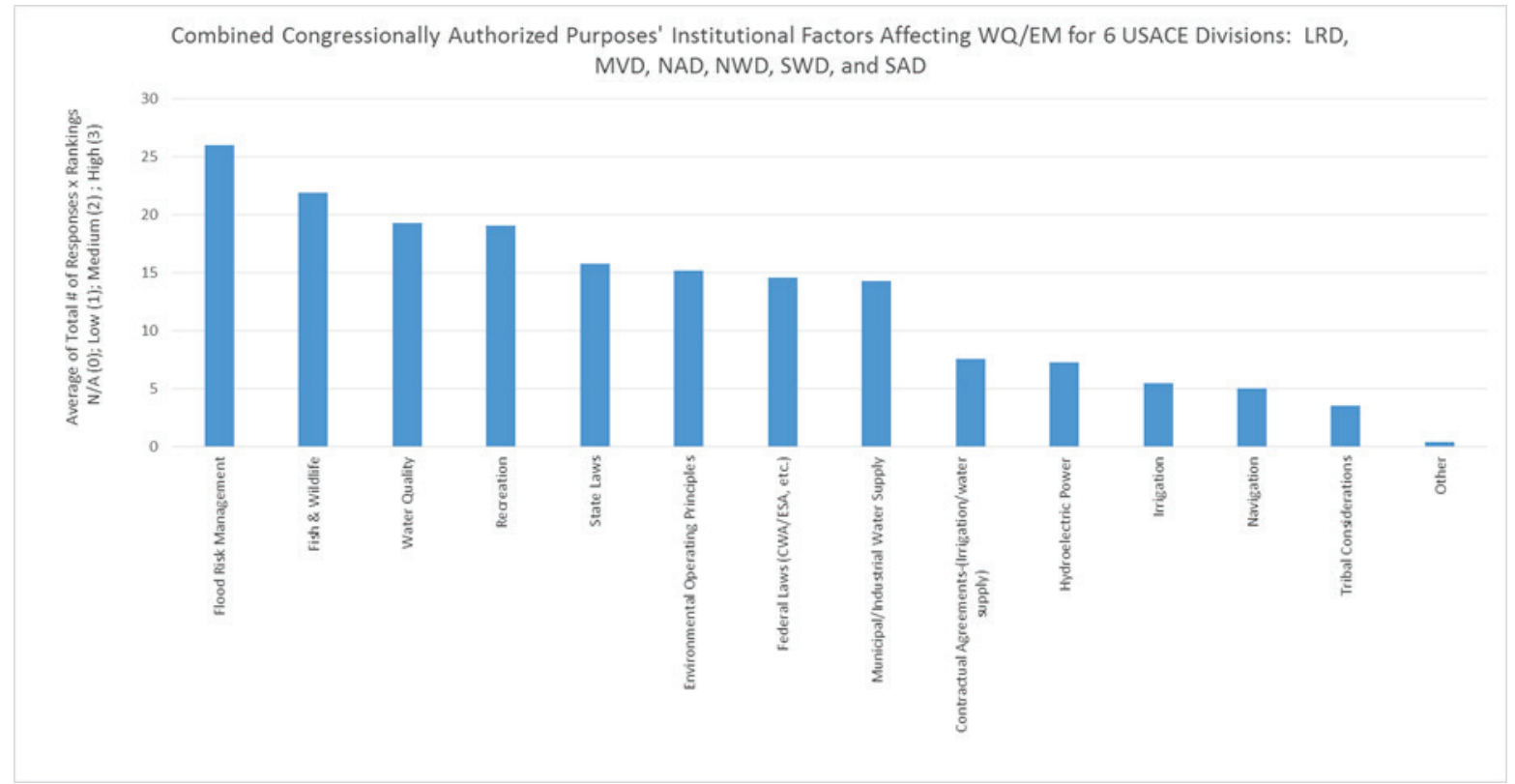

\subsection{Issues}

The next two portions of the survey focused on critical WQ/EM issues facing USACE reservoirs.

\subsubsection{In-reservoir}

Figure 9 summarizes in-reservoir issues of highest concern as identified by the survey. The top two in-reservoir WQ/EM issues were primary and secondary water contact. Fisheries and nutrients were third and fourth.

\subsubsection{Downstream}

Figure 10 summarizes WQ/EM Downstream issues (the top 20). Fish and wildlife management followed by low flow enhancement were the top downstream issues. Secondary contact recreation and environmental management were the next two highest ranked downstream issues. A broad number of other issues received significant scores. 


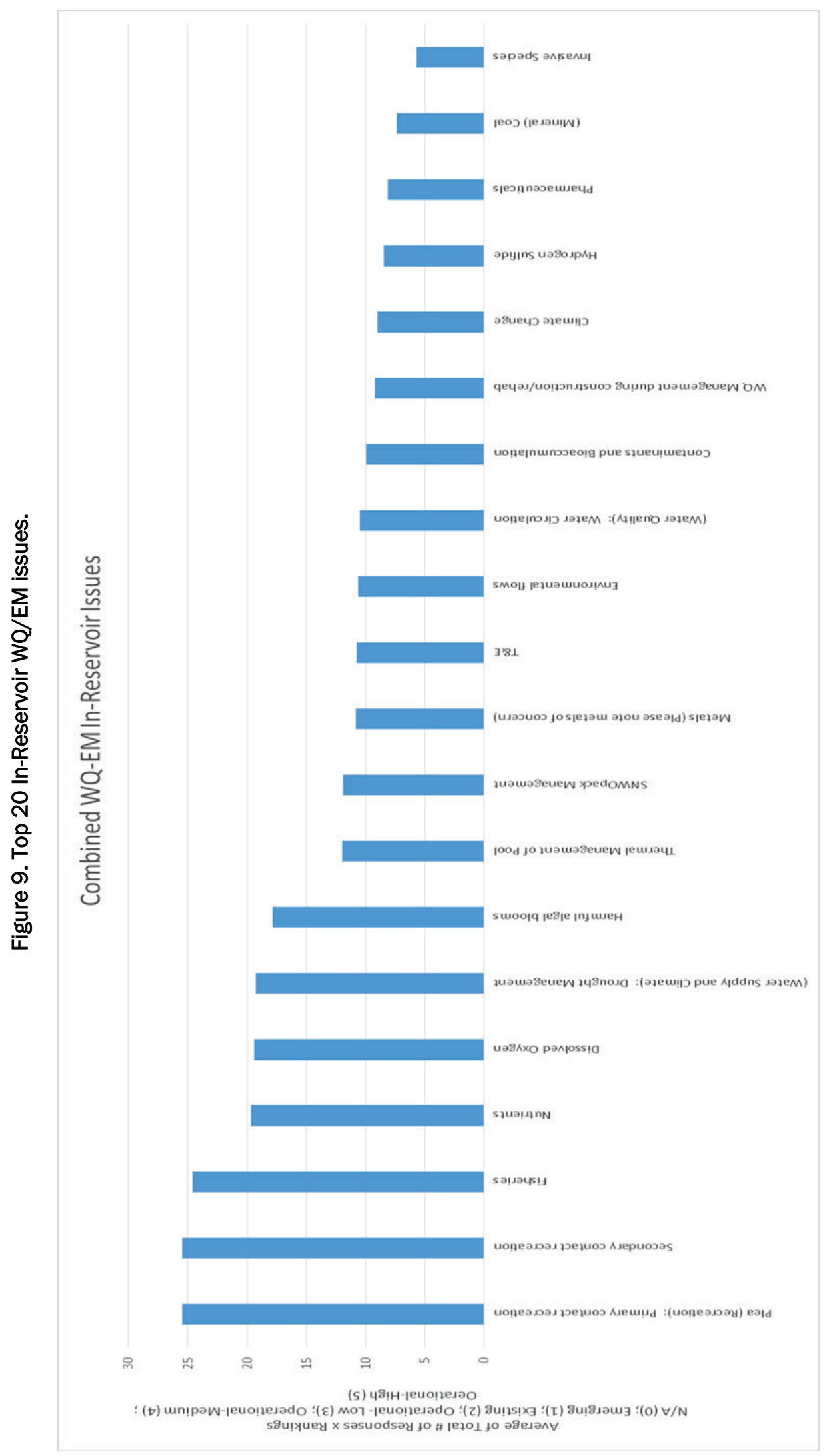




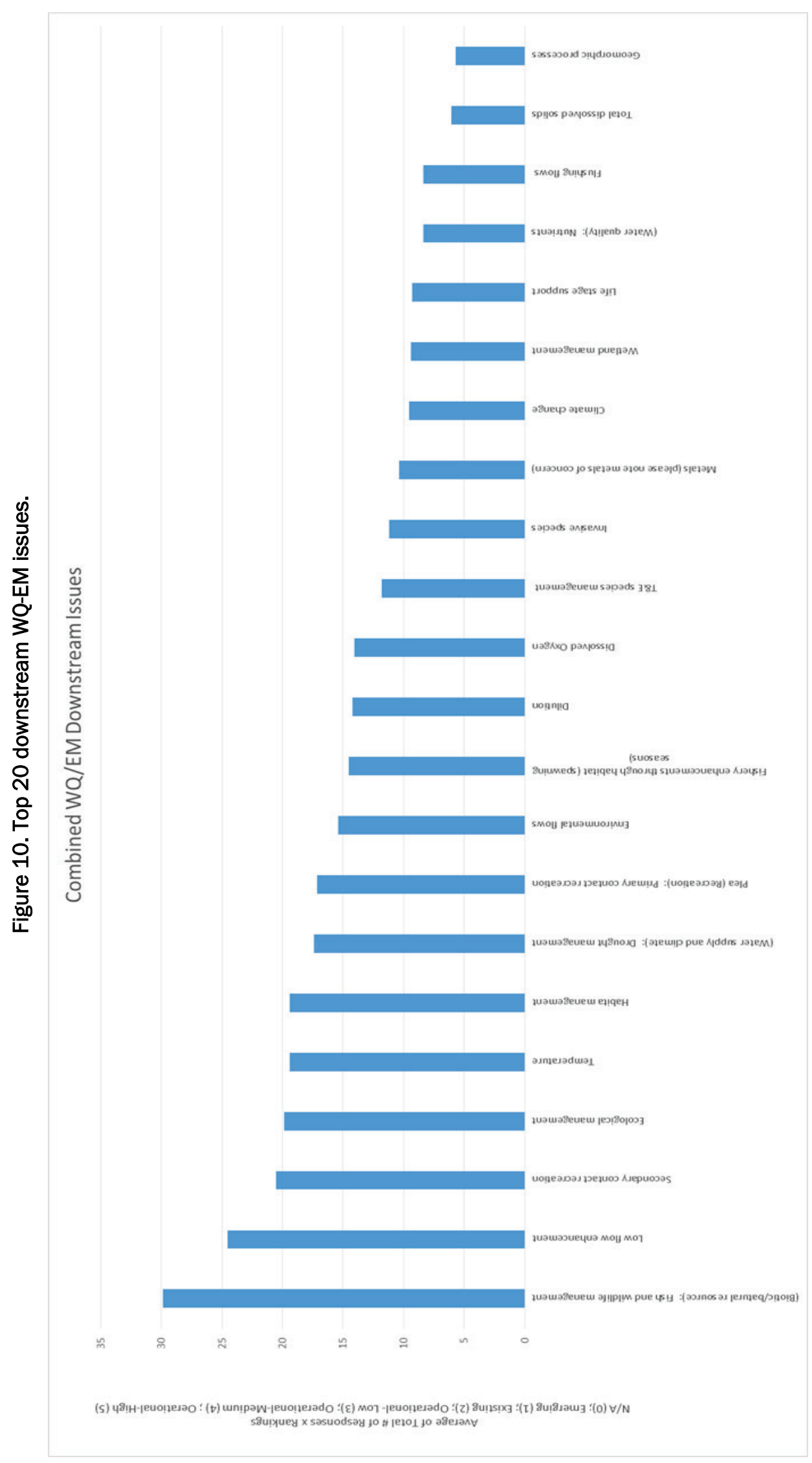




\subsection{TMDL impacts}

The WQ/EM surveys also addressed the impact of legally enforceable Total Maximum Daily Loads (TMDL) on reservoir operation. As part of the CWA, a listing of impaired water bodies was required, which is known as the 303(d) list. A TMDL is a legally enforceable plan that limits input of water constituents and contaminants for a given 303(d) listed stream or water body so that it can meet water quality standards. In assessing the TMDL impacts, the following questions were addressed:

- Is any part of the reservoir or downstream water bodies within the range of management of the dam listed as 303d impaired (Y-N)?

- Does this law influence operations of this reservoir (Y-N)?

- Non-point source pollutants - (for existing TMDLs, mark constituents that apply and provide approximate year when TMDL began influencing operations; if a TMDL has been issued or is pending and is anticipated to influence operations, but has not done so yet, please enter TBD for year; an optional comment field is provided).

- Point source pollutants - (for existing National Pollution Discharge Elimination System (NPDES) permits, provide source, pollutant regulated, and approximate year when permit began influencing operations; if a permit has been issued or is pending and is anticipated to influence operations, but has not done so yet, please enter TBD for year; an optional comment field is provided).

Any yes or no response was considered to be a project area under consideration. Any yes response was determined to be a TMDL impact. So, the percent impacted was determined to be the yes responses divided by the total responses.

Table 4 summarizes the results of this analysis. Survey participants indicated that about $65 \%$ of the projects had a TMDL impairment and $33 \%$ were $303 \mathrm{~d}$ listed. Metals and temperature affected the highest percentage of projects evaluated, however, DO, dissolved gases, metals, sediment, toxins, and nutrients were also identified as common water quality factors being addressed through TMDL implementation.

Finally, there were 38 permits identified, with no pending permits listed. 
Table 4. Clean Water Act (CWA) impacts (TMDLs).

\begin{tabular}{|l|c|}
\hline Percent Projects Impaired Waters and TDMLs (279 projects) & Percent \\
\hline Percent listing impairment affecting management of the project & $64.9 \%$ \\
\hline Percent listing CWA influences operations of this reservoir & $33.0 \%$ \\
\hline & \\
\hline Percent Projects Affected by Nonpoint Source Pollutants TDMLs (210 projects) & $17.6 \%$ \\
\hline Temperature & $15.7 \%$ \\
\hline Dissolved Oxygen & $12.4 \%$ \\
\hline Total Dissolved Gas & $21.0 \%$ \\
\hline Metals & $8.1 \%$ \\
\hline Sediment & $3.8 \%$ \\
\hline Toxins & $16.7 \%$ \\
\hline Nutrients (32 projects identified by SWT) & \\
\hline & \\
\hline Permits & 38 \\
\hline Existing permits & 0 \\
\hline Pending Permits & \\
\hline
\end{tabular}

\subsection{Threatened and Endangered Species (TES)}

According to USACE (1996), all Federal department and agencies are required to conserve threatened and endangered species (TES) on all project lands and waters. Therefore, reservoirs need to be managed in a manner to protect TES. This includes inventories of TES, mapping locations, and conducting activities to conserve TES while allowing them to thrive.

Figure 11 shows results for the districts included in this study for number of TES influences. These influences could be listing of TES or events in which TES affected operations. These range from o for several districts, and as high as 38 for SWT. No data was reported from MVD and MVI. 
Figure 11. Number of TES Influences as reported by the districts responding to the WQ/EM survey.

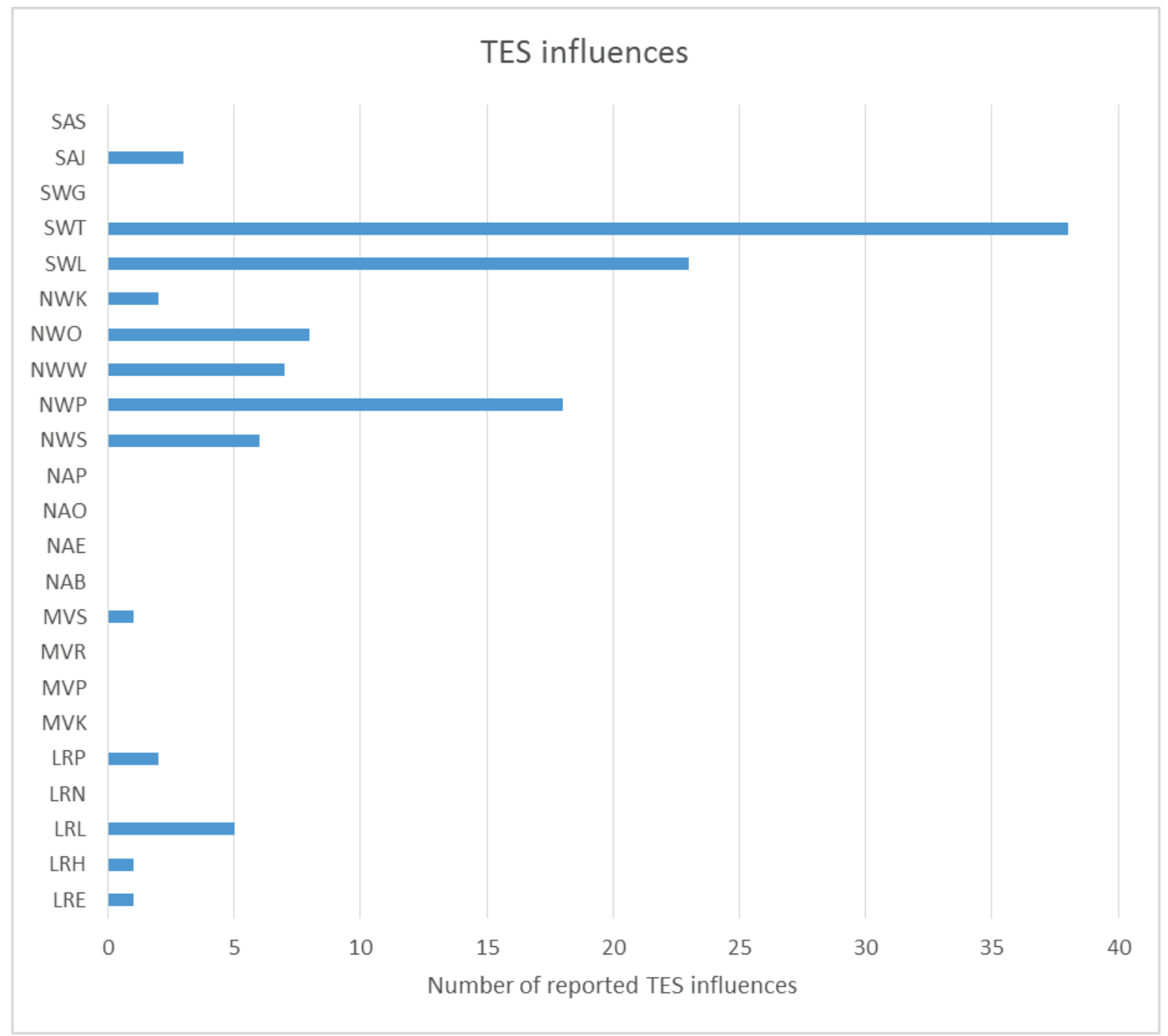

SWT had the most positive responses for TES, the project focused on this district for specifics on the organisms involved in TES actions. Table 6 summarizes the species reported by SWT as affecting operations. TES include bird, mussel, fish, mammalian, reptilian, and insect species. Habitat loss is the most common reason for listing followed by flow alteration. Dates of listing range from 1967-2015 (Table 6). 
Table 5. TES listed by SWT.

\begin{tabular}{|c|c|c|c|}
\hline & Organism & Date & Issue \\
\hline \multirow{6}{*}{$\begin{array}{l}\text { Bird } \\
\text { Species }\end{array}$} & Least Tern & 1985 & Habitat Loss \\
\hline & Piping Plover & 1985 & Habitat Loss \\
\hline & Black-capped Vireo & 1987 & Habitat Loss \\
\hline & Red Knot & 2015 & Habitat Loss \\
\hline & Whooping crane & 1967 & Habitat Loss \\
\hline & $\begin{array}{l}\text { Red-cockaded } \\
\text { Woodpecker }\end{array}$ & 1970 & Habitat Loss \\
\hline \multirow{5}{*}{$\begin{array}{l}\text { Mussel } \\
\text { Species }\end{array}$} & Neosho Mucket & 2013 & $\begin{array}{l}\text { Habitat loss \& flow } \\
\text { alteration }\end{array}$ \\
\hline & $\begin{array}{l}\text { Ouachita Rock } \\
\text { Pocketbook }\end{array}$ & 1991 & $\begin{array}{l}\text { Habitat loss \& flow } \\
\text { alteration }\end{array}$ \\
\hline & Rabbitsfoot & 2013 & $\begin{array}{l}\text { Habitat loss \& flow } \\
\text { alteration }\end{array}$ \\
\hline & Scaleshell Mussel & 2001 & $\begin{array}{l}\text { Habitat loss \& flow } \\
\text { alteration }\end{array}$ \\
\hline & Winged mapleleaf & 1991 & $\begin{array}{l}\text { Habitat loss \& flow } \\
\text { alteration }\end{array}$ \\
\hline \multirow{4}{*}{$\begin{array}{l}\text { Fish } \\
\text { Species }\end{array}$} & Neosho madtom & 1990 & Habitat loss \\
\hline & Topeka Shiner & 1998 & Flow alteration \\
\hline & Leopard darter & 1978 & Habitat loss \\
\hline & $\begin{array}{l}\text { Arkansas River } \\
\text { Shiner }\end{array}$ & 1998 & Habitat loss \\
\hline \multirow{4}{*}{$\begin{array}{l}\text { Mammalian } \\
\text { Species }\end{array}$} & $\begin{array}{l}\text { Northern long-eared } \\
\text { bat }\end{array}$ & 2015 & Habitat loss \\
\hline & Gray bat & 1976 & Habitat loss \\
\hline & Indiana bat & 1967 & Habitat loss \\
\hline & Ozark big eared bat & 1979 & Habitat loss \\
\hline Reptilian Species & American alligator & 1967 & \\
\hline \multirow{2}{*}{$\begin{array}{l}\text { Insect } \\
\text { Species }\end{array}$} & $\begin{array}{l}\text { American burying } \\
\text { beetle }\end{array}$ & 1989 & Habitat loss \\
\hline & $\begin{array}{l}\text { Rattlesnake-master } \\
\text { borer moth }\end{array}$ & & \\
\hline
\end{tabular}




\section{Conclusions}

The following conclusions were drawn from the analysis of the surveys:

- Flood Risk management is a strong driver in USACE operations. It is the number one CAP, had the highest reported funding, and the combined staffing of hydrologists and hydraulic engineers represent key personnel for addressing flooding issues.

- Water quality issues were also key, with algal issues, nutrients, and temperature being of high importance.

- Agricultural issues dominate upstream factors effecting WQ/EM, particularly nutrients, erosion, and pesticides.

- Recreational fishing, algal blooms, DO, and thermal issues were the top in-reservoir factors effecting WQ/EM.

- Primary and secondary contact were the most important issues for both in-reservoir and downstream.

- A very broad range of issues and drivers received significant scores.

- TMDLs resulting from the enforcement of the CWA can affect reservoir operations. Temperature is the most listed issue, but DO, dissolved gas, metals, sediment, toxins, and nutrients are also significant TMDL drivers.

- TES also can affect operations, although its reported impact varies from district to district. Habitat loss is the greatest reason given for impact. A wide range of endangered bird, mussel, mammalian, reptilian, fish, and insect species are listed.

The survey highlights the importance of WQ/EM considerations to reservoir management. 


\section{Discussion}

\subsection{Implication of WQ/EM results}

\subsubsection{Broad set of WQ/EM purposes, factors, and issues}

This analysis identified the most common issues. In addition, it was found that in most cases there are many issues that received lower levels of responses on the survey, but still were significant. For example, in terms of reservoir regulation time spent meeting particular CAPs, flood risk management had the highest percentage at $31 \%$ with other CAPs ranging from $4-12 \%$. These include diverse issues such as water quality, navigation, recreation, and hydroelectric power. Similar results were found for almost all of the remaining survey results. There is a long tail of diverse factors, issues, etc. with lower, but still significant responses.

\subsubsection{Limited Staffing}

The surveys indicated that each district has 1.86 FTE with WQ/EM capabilities. As discussed, USACE districts have a very diverse set of purposes, factors, and issues to deal with. Of course, expertise could be derived from staff in other districts, including ERDC. Contract expertise can also be used as well. Still, this suggests that many issues are addressed by personnel outside their areas of expertise. 


\section{References}

Bartsch, A. F. 1972. Role of Phosphorus in Eutrophication. EPA-R3-72-001. Washington, DC: United States Environmental Protection Agency (USEPA).

Frankel, T. C. 2018. Taming the mighty Mississippi. The Washington Post. 14 March 2018. https://www.washingtonpost.com/graphics/2018/national/mississippi-riverinfrastructure/?utm_term=.f482d4273e4f.

Herman, B., J. Eberly, C. Jung, and V. F. Medina. 2017. Review and Evaluation of Reservoir Management Strategies for Harmful Algal Blooms. ERDC/EL TR-1711. Vicksburg, MS: U.S. Army Engineer Research and Development Center.

Medina, V. F. 2015. Evaluation of Environmentally Acceptable Lubricants (EALs) for Dams Management by the U.S. Army Corps of Engineers. ERDC-TN-WQTNMS-9. Vicksburg, MS: U.S. Army Engineer Research and Development Center. http://acwc.sdp.sirsi.net/client/en_US/search/asset/1045297.

Medina, V. F., K. Pokrzywinski, and E. Martinez-Guerra. 2018B. Evaluation of Koontz Lake (North Indiana) Ecological Restoration Options - Comparison of Dredging and Aeration - and Broad Application to USACE Projects. ERDC/EL TR 18-2. Vicksburg, MS: U.S. Army Engineer Research and Development Center.

Medina, V. F., M. Wynter, C. Jung, A. Russell, T. Paulus, and C. S. Griggs. 2018A. Evaluation of Sulfide Emissions from a Hydraulic System at the Blue River Dam. ERDC/EL TR-18-5. Vicksburg, MS: U.S. Army Engineer Research and Development Center.

Medina, V. F., M. T. Wynter, T. M. Paulus, and J. R. Wilson. 2018C. Analysis of Environmentally Acceptable Lubricants (EALs) for U.S. Army Corps of Engineers (USACE) Dams. ERDC/EL TR-18-15. Vicksburg, MS: U.S. Army Engineer Research and Development Center.

Paulus, T. M., V. F. Medina, T. J. Keyser, B. T Rundgren, M. K. Hess, J. L. Sills. 2018. Mechanical Equipment Lubrication Standardization and Sustainability. Inland Navigation Design Center. INDC TR-2018-1. Rock Island, IL.

Stockton, S. L. 2019. Clean Water Act Compliance at USACE Hydropower Facilities. Memorandum for All Division, Center, Laboratory, and Field Operating Activity Commanders. CECW-CO. Washington, D.C.

United States Army Corps of Engineers (USACE). 1996. Environmental Stewardship and Maintenance Guidance and Procedures. EP 1130-2-540. Washington DC: United States Army Corps of Engineers (USACE).

United States Army Corps of Engineers (USACE). 2017. Management of Water Control Systems. Engineer Manual. EM 1110-2-3600. Washington, DC: United States Army Corps of Engineers (USACE).

United States Army Corps of Engineers (USACE). 2018. Water Quality and Environmental Management for Corps Civil Works Projects. EP 1110-2-8154. Washington DC: United States Army Corps of Engineers (USACE). 
United States Army Corps of Engineers - Institute for Water Resources (USACE-IWR). 2010. Civil Works. Water Resources. Value to the Nation. Washington, DC: United States Army Corps of Engineers (USACE).

United States Army Corps of Engineers - Institute for Water Resources (USACE-IWR). 2016a. Status and Challenges for USACE Reservoirs. 2016-R-oX. Washington, DC: United States Army Corps of Engineers (USACE).

United States Army Corps of Engineers-Institute of Water Resources. (USACE-IWR). 2016b National Portfolio for Reallocations Assessment of Data: Status and Challenges for USACE Reservoirs, 2016-RES-01. Washington, DC: United States Army Corps of Engineers (USACE).

Webb, J., and T. Hillyer. 2008. Survey for the Water Supply Reallocation Portfolio Assessment and Water Management and Sediment Management aspects of Corps Projects. Cover Letter for WQ-EM Surveys. USACE Civil Works and Institute for Water Resources. Washington, DC: United States Army Corps of Engineers (USACE). 


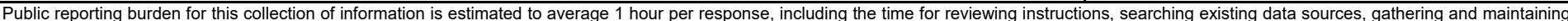

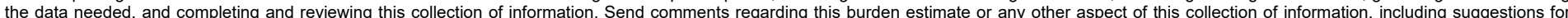

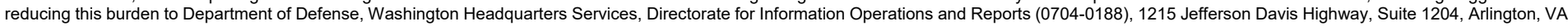

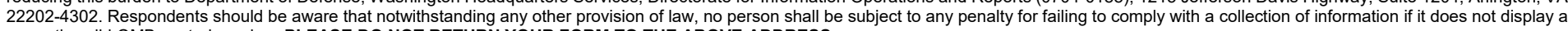
currently valid OMB control number. PLEASE DO NOT RETURN YOUR FORM TO THE ABOVE ADDRESS.

\begin{tabular}{l|l|l} 
1. REPORT DATE $(D D-M M-Y Y Y Y)$ & 2. REPORT TYPE & 3. DATES COVERED (FrOm - To)
\end{tabular}

August 2019 Final report

\section{TITLE AND SUBTITLE}

Evaluation of Water Quality/Environmental Management Surveys on USACE Managed

Reservoirs and Waterways

\section{AUTHOR(S)}

Victor F. Medina, Afrachanna D. Butler, Erich B. Emery, and Gerard A. "Tony” Clyde

5a. CONTRACT NUMBER

5b. GRANT NUMBER

5c. PROGRAM ELEMENT NUMBER TA2017-003

5d. PROJECT NUMBER

5e. TASK NUMBER

5f. WORK UNIT NUMBER

\section{PERFORMING ORGANIZATION NAME(S) AND ADDRESS(ES)}

8. PERFORMING ORGANIZATION REPORT NUMBER

U.S. Army Engineer Research and Development Center,

Environmental Laboratory

ERDC/EL TR-19-11

3909 Halls Ferry Road, Vicksburg, MS 39180-6199

\section{SPONSORING / MONITORING AGENCY NAME(S) AND ADDRESS(ES)}

Headquarters, U.S. Army Corps of Engineers

Washington, DC 20314-1000

10. SPONSOR/MONITOR'S ACRONYM(S)

WOTS

11. SPONSOR/MONITOR'S REPORT NUMBER(S)

\section{DISTRIBUTION / AVAILABILITY STATEMENT}

Approved for public release; distribution unlimited.

\section{SUPPLEMENTARY NOTES}

\section{ABSTRACT}

This technical report (TR) details the results of a water quality/environmental management (WQ/EM) survey that was provided to U.S. Army Corps of Engineers (USACE) districts and divisions. The WQ/EM survey found that flood risk management was the most important congressionally authorized purpose, and was the highest funded activity. These results were followed by water quality, navigation, and recreation for importance. Agricultural impacts (i.e., nutrients, erosion, and pesticides) were the most critical upstream factors affecting WQ/EM. Critical reservoir factors were fisheries and algal blooms. In most cases, the results showed that there were very broad sets of WQ/EM purposes, factors, and issues. Limited resources in terms of funds and personnel will have to be applied to maximize positive benefits.

$\begin{array}{lll}\text { 15. SUBJECT TERMS } & \text { Water quality } & \text { Environmental management } \\ & \text { Water quality management } & \text { United States. Army. Corps of Engineers-- } \\ & \text { United States. Army. Corps of Engineers-- } & \text { Civil function } \\ & \text { Surveys } & \end{array}$

\section{SECURITY CLASSIFICATION OF:}

\section{a. REPORT}

UNCLASSIFIED

b. ABSTRACT
UNCLASSIFIED

17. LIMITATION OF ABSTRACT
18. NUMBER OF PAGES

c. THIS PAGE

UNCLASSIFIED

\section{9a. NAME OF RESPONSIBLE} PERSON

19b. TELEPHONE NUMBER (include

43 area code) 